\title{
PENERAPAN MODEL PEMBELAJARAN REALISTIC MATHEMATICS EDUCATION (RME) TERHADAP KEMAMPUAN PEMAHAMAN KONSEP MATEMATIS SISWA
}

\author{
${ }^{1}$ Reta Sastia \\ ${ }^{1}$ Mahasiswa Program Studi Pendidikan Matematika, FKIP, Universitas Muhammadiyah Sukabumi \\ sastiafebilia11@gmail.com
}

\begin{abstract}
Abstrak
Penelitian ini bertujuan untuk melihat adanya pengaruh pendekatan matematika realistik terhadap kemampuan pemahaman konsep matematika siswa kelas VIII SMP pada materi prisma. Metode penelitian yang digunakan dalam penelitian ini adalah metode kualitatif dengan jenis penelitian studi kepustakaan. Dari hasil tersebut dapat disimpulkan bahwa penggunaan model pendekatan Realisik Matematika Education (RME) berpengaruh positif terhadap kemampuan pemahaman konsep matematika, hal ini disebabkan karena dalam penerapan model pembelajaran tersebut (1) Siswa dapat membangun sendiri pengetahuannya sehingga siswa dapat lebih mudah memahami konsep dan tidak mudah lupa dengan pengetahuannya, (2) Siswa diberikan permasalahan matematika yang berkaitan dengan permasalahan kehidupan sehari-hari mereka, (3) Kegiatan di dalam kelas pada saat proses belajar menarik dan juga menyenangkan oleh sebab itu siswa lebih cepat memahami konsep dan tidak cepat bosan untuk belajar matematika.
\end{abstract}

Kata Kunci : Realistic Mathematics Education (RME), Model Pembelajaran Realistic Mathematics Education (RME), kemampuan pemahaman konsep matematika.

\section{PENDAHULUAN}

Matematika adalah salah satu mata pelajaran yang di ajarkan di semua jenjang pendidikan di Indonesia. "Pembelajaran matematika adalah suatu proses yang sengaja di rancang dengan tujuan untuk menciptakan suasana lingkungan yang memungkinkan seseorang melaksanakan kegiatan belajar matematika, dan proses tersebut berpusat pada guru dengan melibatkan partisipasi aktif peserta didik di dalamnya" (Hamzah, \& Muhlisrarini, 2014:65). Tujuan pembelajaran pendidikan matematika yang secara umum di ajarkan di sekolah sekolah yakni kecakapan dan kemahiran matematika yang di harapkan dalam belajar matematika mulai dari satuan pendidikan SD/MI sampai dengan SMA/Aliah (Hamzah, \& Muhlisrarini, 2014:74).

Tujuan pembelajaran matematika menurut Kemendigbud 2013: (1) Meningkatkan kemampuan intelektual, khususnya kemampuan tingkat tinggi siswa. (2) Membentuk kemampuan secara sistematik pada siswa dalam menyelesaikan permasalahan matematika. (3) Memperoleh hasil belajar yang tinggi. (4) Melatih siswa dalam mengkomunikasikan ide-ide. (5) Mengembangkan karakter siswa.

Salah satu cara untuk mencapai tujuan pembelajaran matematika yaitu dengan mampu memahami konsep matematika. Pemahaman konsep merupakan seuatu kemampuan dalam mengaitkan skema-skema tertentu yang sesuai dengan konsep. Pemahaman adalah ilmu yang telah terbentuk dalam bayangan mental seseotang berdasarkan pengalaman belajar sebelumnya. Terdapat beberapa indicator dalam pemahaman konsep diantaranya : (1) kemampuan seseorang dalam mengungkapkan kembali hal yang telah di komunikasikan kepadanya dengan kata lain dia mampu menyatakan ulang sebuah konsep; (2) kemampuan seseorang dalam mengelompokan suatu objek menurut sifat-sifatnya atau mengklasifikasikan objek (sesuai dengan konsepnya); (3) kemampuan seseorang dalam membuat grafik, menggambarkan objek, membuat ekspresi matematis; (4) kemampuan seseorang dalam mengaplikasikan konsep atau algoritma dalam menyelesaikan masalah secara tepat, akurat, luwes dan efisien; (5) dan kemampuan seseorang dalam memberikan contoh dan bukan contoh dari materi yang telah di pelajarinya. Dengan kata lain Peserta didik dikatakan mampu memahami konsep apabila dia dapat menguasai indicator-indikator tersebut dengan demikian peserta didik akan mampu memahami materi secara utuh dan dapat menggunakan matematik dalam konteks di luar matematika. namun sayangnya tujuan dari pembelajaran matematika sampai saat ini belum bisa terwujud dengan baik salah satu faktornya adalah masih banyak peserta didik dalam penguasaan konsep masih berada ditataran yang rendah. 
Meskipun pemahaman konsep matematika merupakan aspek penting, namun masih terdapapat banyak siswa yang lemah dalam hal pemahaman konsep matematika. Kelemahan kemampuan pemahaman konsep matematika siswa dapat dilihat memalui hasil penelitian terbaru Berdasarkan hasil pemelitian RISE (Research on Improvement of System Education), pada tahun 2018 Indonesia sudah gawat darurat dalam matematika, RISE merilis hasil penelitian yang membahas soal kemampuan matematika perbandingan antara siswa SD/MI dengan siswa yang tamat SMA/MA tidak jauh berbeda. Yang di maksud gawat darurat matematika yaitu kemampuan siswa dalam matematika tidak mengalami perkembangan seiring bertambahnya usia dan tingkat sekolah. Menurut Niken (dalam penelitian RISE : 2018) penurunan kemampuan matematika terjadi dari tahun ketahun. “ Data PISA ( Programme for internasional Syudent Assessment) menyebutkan tahun 2000 hingga 2015 secara konsisten menempatkan siswa-siswi Indonesia yang berusia 15 tahun pada peringkat bawah diantara Negara-negara lain anggota OECD (Organization for Economic Co-operation and Development). " (Citra Larasati, 2018). Hasil Penelitian tersebut menandakan bahwa siswa Indonesia sangat kurang dan lemah dalam matematika. Kondisi ini dikhawatirkan memberikan dampak buruk terhapad kemampuan siswa dalam memahami konsep, bernalar, berfikir serta penyelesaian dalam menghapadi permasalahan sehari-hari. Dari Uraian tersebut kita diberikan suatu gambaran bahwa penguasaan pemahaman konsep matematik di sekolah-sekolah sangatlah penting.

Berdasarkan hasil pengamatan di beberapa sekolah di kabupaten Sukabumi salah satunya di SMP al-masyhad, kemampuan pemahaman konsep matematik siswa disana juga tergolong masih rendah. Maka dari itu, di butuhkan suatu model pembelajaran matematik yang tepat sehingga kemampuan pemahaman konsep matematik siswa dapat meningkat. Mel Silberman yang diterjemahkan oleh Yovita Hardiwati (2013, hlm. ix) menyatakan bahwa: "Anda dapat memberitahukan para murid hal-hal yang perlu mereka ketahui dengan sangat cepat. Tetapi, mereka akan melupakannya dengan lebih cepat lagi." Dari pernyataan diatas, terlihat bahwa pentingnya pemilihan media, kemampuan guru dalam menyajikan pembelajaran serta penggunaan model pembelajaran yang tepat. Model pembelajaran yang di pilih haruslah sesuai materi yang akan diajarkan dan haruslah dapat mengoptimalkan suasana belajar di kelas.

Model pembelajaran yang sesuai untuk digunakan dalam mengatasi permasalahan kurangnya kemampuan pemahaman matematika ialah model Pembelajaran Realistic Mathematics Education (RME) yang dipopulerkan oleh Prof. Hans Freudenthal. "Freudenthal memandang bahwa pembelajaran matematika sebagai suatu aktifitas yang dilakukan oleh manusia. Pandangan matematika sebagai suatu aktifitas manusia merujuk pada proses pembelajaran matematika yang memberikan kesempatan kepada peserta didik untuk melakukan kegiatan eksplorasi terhadap penomena/kejadian yang dapat dibayangkan oleh peserta didik guna mengembangkan dan membangun pengetahuan mereka, bukan memandang pembelajaran matematika sebagai suatu ilmu yang pembelajarannya melalui pemindahan(transfer) pengetahuan" ( Susilahudin Putrawangsa Susilahudin, 2017, hlm. 33 ). Menurut Freudenthal terdapat tiga peinsip dalam pembelajaran matematika realistic diantaranya (1) guided reinvention yaitu pemenuan kembali secara terbimbing; (2) didactical phenomenology yaitu fenomenologi didaktis; (3) self developed models yaitu dengan mengembangkan mode-model sendiri.

Selanjutnya ada lima karekteristik RME menurut Hobri (2009 : 168-170) (1) the use of context yaitu menggunakan masalah kontekstual; (2) use model, bridging by vertical instruments yaitu Menggunakan model; (3) student contribution yaitu menggunakan kontribusi siswa; (4) Interactivity yaitu menggunakan interaksi; (5) interwintment yaitu menggunakan keterkaitan. Beberapa kelebihan dari penerapan model pembelajaran metematika realistic diantaranya (1) dalam proses pembelajaran dikaitkan dengan kehidupan seharihari juga kegunaan matematika secara umum sehingga memudahkan siswa mengerti materi dengan jelas; (2) Siswa membangun sendiri pengetahuan, sehingga siswa tidak mudah lupa dengan pengetahuannya; (3) Siswa merasa dihargai dan semakin terbuka, karena setiap jawaban siswa diberikanan nilai; (4) Memupuk kerja sama dalam kelompok maupun antar kelompok; (5) siswa dilatih keberanian dalam menjelaskan jawaban di depan kelas; (6) Melatih siswa untuk terbiasa berpikir dan mengemukakan pendapat; (7) Suasana proses pembelajaran menyenangkan karena menggunakan realitas kehidupan, sehingga siswa tidak mudah dan 
tidak cepat bosan belajar matematika; (8) siswa di berikan pendidikan budi pekerti.

Dalam kaitan pentingnya permasalahan di atas, maka diterapkan pembelajaran matematika yang menggunakan model pembelajaran Realistic Mathematics Education (RME) yang bertujuan untuk meningkatkan kemampuan pemahaman konsep matematika siswa. Tujuan dari penelitian ini adalah untuk mengetahui bagaimana efektifitas penerapan Model Pembelajaran Realistic Mathematics Education (RME) terhadap kemampuan pemahaman konsep matematika siswa.

\section{METODE PENELITIAN}

Penelitian ini merupakan penelitian kepustakaan (library research); dilaksanakan dengan menggunakan literatur (kepustakaan) dari penelitian sebelumnya. Penelitian studi pustaka adalah salah satu jenis penelitaian yang di gunakan dalam mengumpulkan informasi dan data yang mendalam melalui berbagai literatur, buku, catatan atau hasil penelitian sebelumnya yang relevan dengan penelitian yang sedang dilakukan tujuannya yaitu agar dapat memperoleh jawaban dan landasan teori mengenai masalah yang akan di teliti . Dalam penelitian ini peneliti melihat dan menghubungakan indicator pemahaman konsep matematik dengan karakteristik dan prinsip- prinsip dari Model Pembelajaran Realistic Mathematics Education (RME) siswa

\section{HASIL DAN PEMBAHASAN}

Berdasarkan prinsip dan karakteristik realistic mathematics education (RME), diperoleh langkah-langkah dalam proses pembelajaran yaitu sebagai berikut :

- Langkah 1 : kegiatan memahami masalah kontekstual,

- Langkah 2 : kegiatan menjelaskan masalah kontekstual.
- Langkah 3 : kegiatan menyelesaikan masalah kontekstual.

- Langkah 4 : kegiatan membandingkan dan mendiskusikan jawaban.

- Langkah 5 : kegiatan menyimpulkan.

Langkah-langkah pembelajaran tersebut diimplementasikan melalui penggunaan LKS, materi prisma. Sehingga di desai LKS berbasis RME dengan tujuan agar dapat membantu guru dalam penerapan model pembelajaran realistic mathematics education (RME) dan untuk memudahkan siswa dalam memahami konsep matematika yang akan dipelajari.

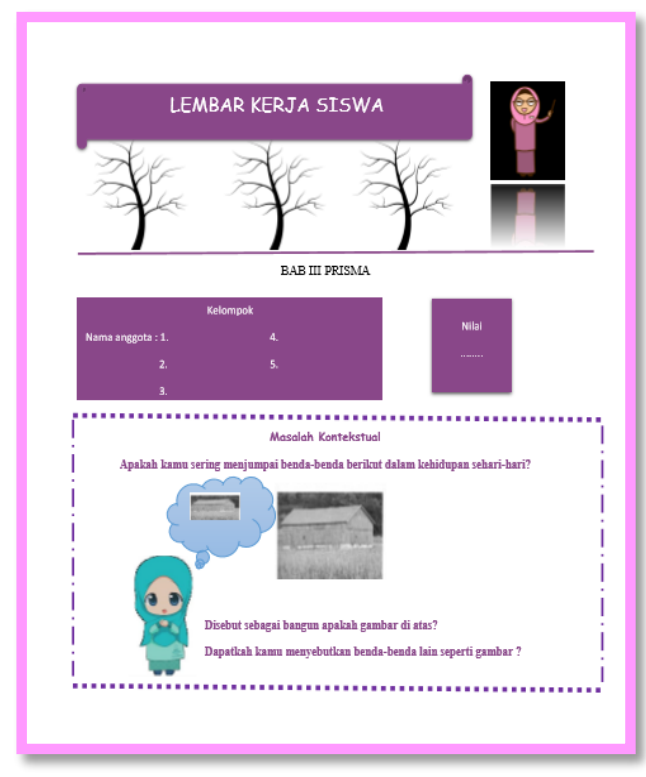

Gambar 1. Lembar kegiatan

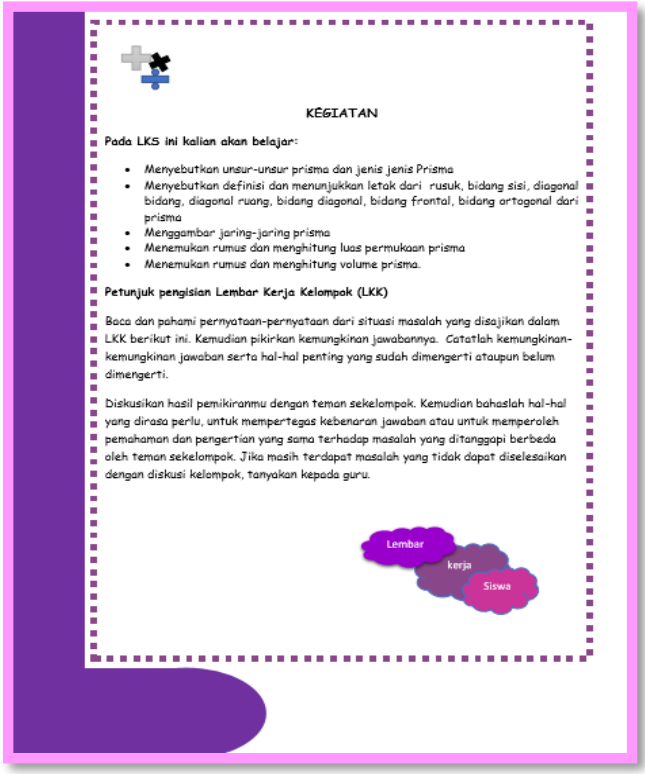

Gambar 2. Lembar kegiatan 
Dari gambar di atas dapat dilihat bahwa dalam penerapan model pembelajaran Realistic Mathematics Education (RME), siswa dikenalkan penjelasan mengenai situasi dan masalah konstekstual soal dengan memberikan petunjuk/saran seperlunya terhadap bagian yang belum siswa pahami kemudian siswa di arahkan untuk menemukan unsur-unsur yang dikaitkan dengan unsur-unsur matematika mengenai prisma dan jenis-jenis prisma dengan melakukan secara berkolompok kegiatan LKS yang akan diberikan.(Student contribution, Karakteristik $R M E$ ). Dalam LKS gambar di atas masalah konstektuan yang di sajikan adalah bangunan rumah. bangunan rumah merupakan bangunan tempat tinggal. Dari gambar tersebut terdapat beberapa unsur-unsur bangun ruang sisi lengkung: diantaranya prisma segitiga dan prisma segiempat (balok). Dengan adanya kaitan antara pembelajaran matematika dengan permasalahan dalam kehidupan sehari-hari dapat memudahkan siswa menerima materi dan. Memahami konsep Hal ini sejalan dengan pendapat Zulkarnain, sebagaimana dikutip oleh Iwan junaedi ( dalam Ramadhan, 2009: 4), yaitu “ PMRI menekankan untuk membawa matematika pada pembelajaran bermakna dengan mengaitkannya dalam kehidupan nyata sehari-hari yang bersifat realistik. Sehingga pembelajaran menjadi lebih menyenangkan. Melalui pembelajaran ini, peserta didik tidak hanya mudah menguasai konsep dan materi pembelajaran namun juga tidak cepat lupa dengan apa yang telah diperolehnya tersebut sehingga dapat meningkatkan hasil belajar peserta didik".

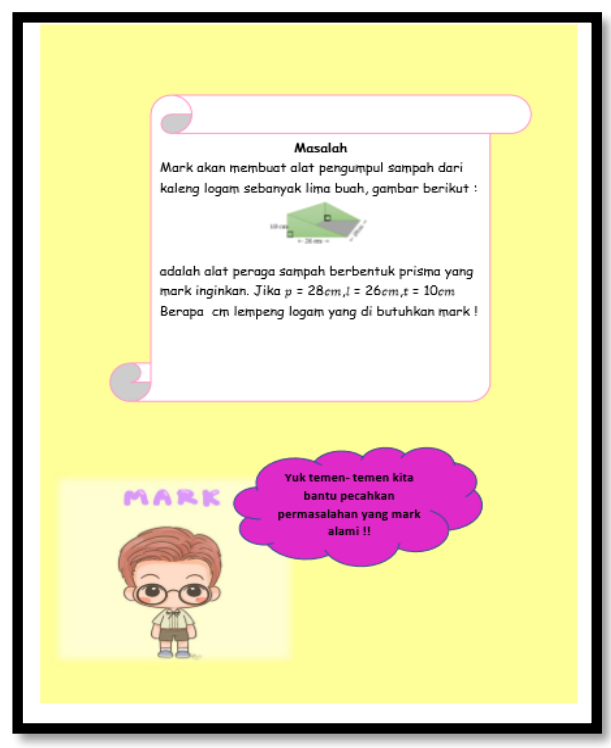

Gambar 3. Contoh Permasalahan
Dengan siswa dilatih untuk memecahkan masalah matematika yang berkaitan dengan kehidupan sehari-hari, maka siswa akan lebih mudah memahami konsep matematika yang di ajarkan di sekolah. Dalam penerapan model realistic ini juga diberikan beberapa konteks pengelolaan kelas yang dilakukan oleh guru disesuaikan dengan nilai dan budaya Indonesia. Dosenpendidikan (dalam, Marpaung, 2009. Menyatakan bahwa terdapat 10 karakteristik PMRI, yaitu:

1. Guru dan peserta didik berperan aktif dalam proses pembelajaran

2. Pembelajaran dimulai dengan menyajikan masalah kontekstual masalah kontekstual yang di maksud di sini sebagai penekanan pada proses pembelajaran yang menghadirkan masalah matematika yang ' dapat di bayangkan para siswa'.

3. Formal Guru memberi kesempatan kepada siswa untuk menyelesaikan masalah yang diberikan guru dengan caranya sendiri. Siswa diberi kesempatan untuk dapat menyelesaikan masalah yang di berikan guru dengan cara dan kemampuannya sendiri.

4. Guru berperan sebagai pendorong terjadinya interaksi dan negoisasi.

5. Dalam kegiatan pembelajaran dikelas Guru menciptakan suasana yang menyenangkan Guru menciptakan suasana pembelajaran yang menyenangkan (menggunakan pendekatan SANI: santun, terbuka dan komunikatif).

6. Adanya keterkaitan antar materi yang diajarkan (prinsip intertwinment).

7. Pembelajaran berpusat kepada peserta didik.

8. Dalam proses pembelajaran Guru bertindak sebagai fasilitator.

9. Jika siswa melakukan kesalahan di dalam menyelesaikan masalah, siswa jangan dimarahi, tetapi disadarkan melalui pertanyaanpertanyaan.

10. Guru sangat mengapresiasi dan menghargai keberanian siswa ketika mengutarakan pendapat dan idenya.

Dalam Memilih dan mengembangkan pemahaman konsep matematika merupakan bagian yang sangat penting. Pemahaman konsep matematik merupakan landasan penting dalam berpikir dan juga menyelesaikan permasalahan matematika maupun permasalahan sehari-hari. Menurut Schoenfeld (1992) berpikir secara matematik berarti (1) mengembangkan suatu pandangan matematik, menilai proses dari matematisasi dan abstraksi, dan 
memiliki kesenangan untuk menerapkannya, (2) mengembangkan kompetensi, dan menggunakannya dalam dalam pemahaman matematik. Oleh karena itu dengan menggunakan model pembelajaran Realistic Mathematics Education (RME) ini kemampuan pemahaman konsep matematika siswa dapat terlatih dengan baik.

Dalam model pembelajaran realistik misalnya ketika siswa diberikan suatu masalah terkait dengan luas permukaan prisma, maka terlebih dahulu siswa digiring untuk menemukan konsep luas permukaan prisma. siswa dituntut untuk dapat mulai mempraktekkan menggunakan alat peraga dengan langkah-langkah yang sesuai . (pada lembar kerja siswa/LKS) (Student contribution, interactivity, Karakteristik,RME);(Guid ed Reinvention,Didactical Phenomology, self developed models), untuk menyelesaikan masalah .(pada lembar kerja siswa/LKS) (Student contribution, interactivity, karakteristik RME), untuk saling membandingkan dan mendiskusikan permasalah dengan anggota kelompok, dan mempresentasikan hasil diskusi.(memahami, menjelaskan, menyelesaikan masalah kontekstual, dan menyimpulkan, langkah 1,2,3,5 RME) (Membandingkan dan mendiskusikan jawaban. Dalam pembelajaran dengan model realistic ini diharapkan dapat meningkatkan pemahaman konsep dan memotivasi siswa dalam belajar. Hal ini dikarenakan dengan menggunakan pembelajaran dengan model realistic, selain siswa belajar tentang matematika siswa juga belajar tentang memecahkan masalah dalam kehidupan nyata di sekitarmya selain itu siswa juga dilatih untuk menemukan sendiri pengetahuannya tentang konsep-konsep matematika dan siswa juga dibiasakan berfikir, mengemukakan pendapatnya suatu masalah dengan alur pemecahan masalah yang tepat.

\section{KESIMPULAN}

Berdasarkan hasil penelitian tersebut maka dapat disimpulkan bahwa penerapan model pendekatan realisik matematika education (RME) berpengaruh positif terhadap kemampuan pemahaman konsep matematis siswa, hal ini disebabkan karena

1. Siswa dapat membangun sendri pengetahuannya sehingga siswa dapat lebih mudah memahami konsep dantidak mudah lupa dengan pengetahuannya, langkah 4 RME). Sehingga dengan adanya aktivitas tersebut siswa dapat lebih mudah memahami konsep matematika dan tidak hanya mendapatkan pengetahuan tentang konsep luas permukaan prisma ari LKS namun berdasarkan hasil pengamatan dan percobaan secara langsung.
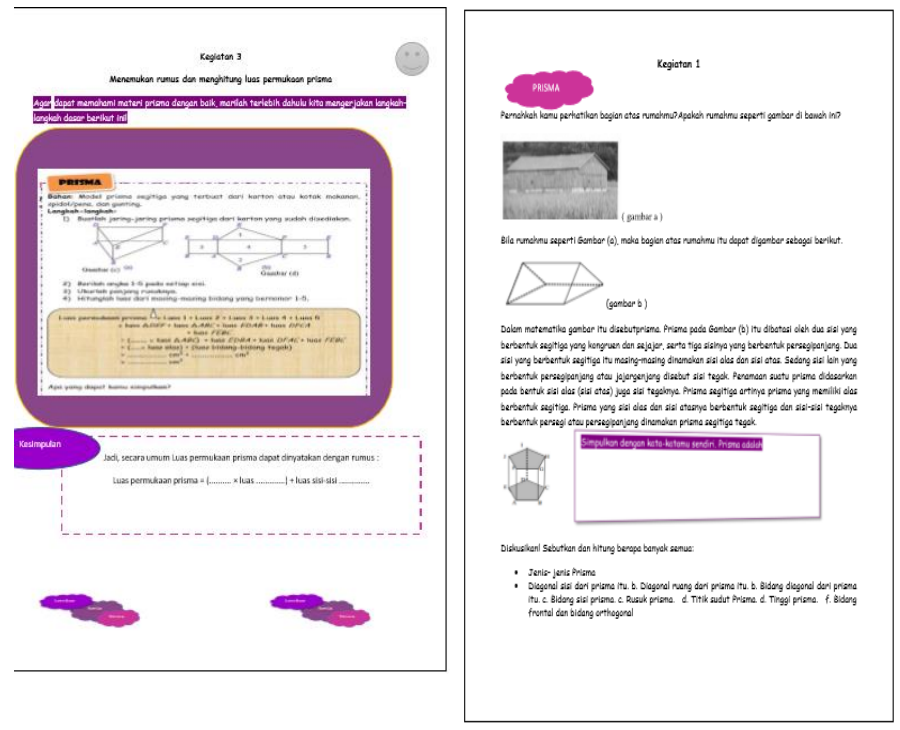

Gambar 4. Lembar Aktivitas Siswa

2. Siswa diberikan permasalahan matematika yang berkaitan dengan permasalahan kehidupan sehari-hari mereka,

3. Kegiatan di dalam kelas pada saat proses belajar menarik dan juga menyenangkan oleh sebab itu siswa lebih cepat memahami konsep dan tidak cepat bosan untuk belajar matematika

\section{DAFTAR PUSTAKA}

Pitaloka, Y. D \& dkk. 2012. Keefektifan Model Pembelajaran Matematika Realistik Indonesia Terhadap Kemampuan Pemahaman Konsep Matematika. Unnes Journal of Mathematics Education.

Hutasuhut, A. R. 2019. Studi literatur meningkatkan kemampuan berpikir kreatif dengan pendekatan pmr matematis siswa. Desember.

Kesumawati, N. 2008. Pemahaman Konsep Matematik dalam Pembelajaran Matematika. Pendidikan Matematika, 2(2), 229-235.

Achmad Achmad, \& Irmansyah. 2011. Efektifitas Pembelajaran Matematika Melalui Model Pembelajaran Realistic Matematic Education (Rme ) Terhadap Peningkatan Pemahaman Konsep Matematika Siswa Sd. Jurnal Pendidikan, 12(1), 33-40. 
Arifuddin, A. 2016. Pembelajaran Matematika Model Quantum Teaching Dengan Pendekatan Realistik Untuk Meningkatkan Kemampuan Pemahaman Konsep Peserta Didik. Al Ibtida: Jurnal Pendidikan Guru MI, 3(2), 186.

Marpaung, Y., \& Julie, H. 2010. PMRI dan PISA : Suatu Usaha Peningkatan Mutu Pendidikan Matematika di Indonesia. P4Mriusd, 1.

Afriansyah, E. A. 2016. Makna Realistic dalam RME dan PMRI. Lemma, II(2), 96-104.

Dosen pendidikan2. 2019. Realistic Matematic Education (RME).https://www.dosenpendidikan.co.id/relisti c-mathematics-education/

Larasati, C 2018. Indonesia Gawat Darurat Matematika.

http://www.medcom.id/pendidikan/newpendidikan/yNLvyWqk-indonesia-gawatdarurat-matematika.

Putrawangsa, S. 2018. Desain pembelajaran matematika realistik. In Desain Pembelajaran Matematika Realistik (Issue November 2017). 